\title{
Rare Presentation of Subclinical Hypothyroidism from a Lingual Thyroid
}

\author{
Choirina Windradi, ${ }^{1}$ Soebagijo Adi Soelistijo, ${ }^{1}$ Sony Wibisono Mudjanarko, ${ }^{1}$ Muhtarum Yusuf ${ }^{2}$
}

${ }^{1}$ Department of Internal Medicine, Airlangga University, Faculty of Medicine, Airlangga University Hospital

${ }^{2}$ Department of Otolaryngology, Airlangga University, Faculty of Medicine, Airlangga University Hospital

\section{Key words: subclinical hypothyroidism, ectopic thyroid, lingual thyroid, levothyroxine}

A 25-year-old female, presented with a posterior lingual mass, without pain nor bleeding (Figure 1). She became more prone to shortness of breath upon exercise and felt uncomfortable swallowing solid food but denied snoring, cold intolerance, or unintentional weight gain. Examination revealed a mass posterior to her tongue and no palpable thyroid gland at the thyroid fossa. Investigations revealed thyroid function tests (TFTs): FT4 $1.29 \mu \mathrm{g} / \mathrm{dl}$ (0.89-1.76); TSH 17,049 IU/ml (0.55-4.78); T3 total $1.27 \mu \mathrm{g} /$ dl (0.6-1.81). Fiber optic laryngoscopy showed a smooth, slippery, unilocular mass attached to the base of tongue. CT cervical-head showed a high-density $2.6 \times 2.2 \times 2 \mathrm{~cm}^{3}$ soft tissue mass posterior to the tongue, which narrowed the airway to a diameter of $0.4 \mathrm{~cm}$ (Figure 2). The mass was likely to be thyroid tissue. To reduce the obstructive symptoms from the mass we did excisional surgery followed by the administration of levothyroxine $25 \mu \mathrm{g}$ once daily. She had no complaints after surgery. A followup thyroid function profile showed FT4 1.46; TSH 6.467; T3 1.59. Histopathology of the tissue revealed multiple thyroid follicles consistent with ectopic thyroid (Figure 3).

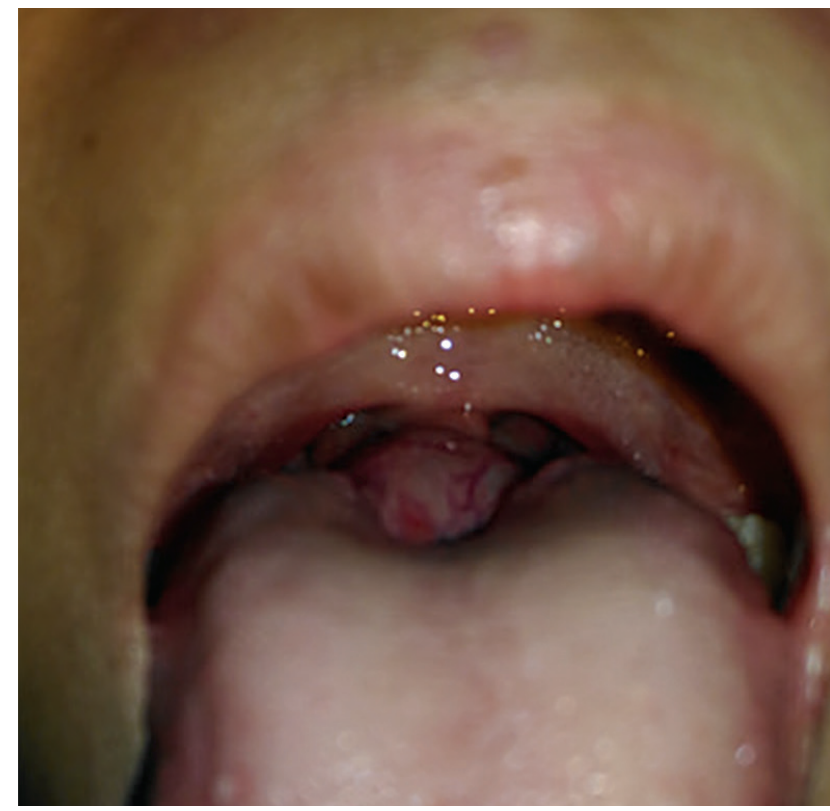

Figure 1. Lingual thyroid in the oropharynx.
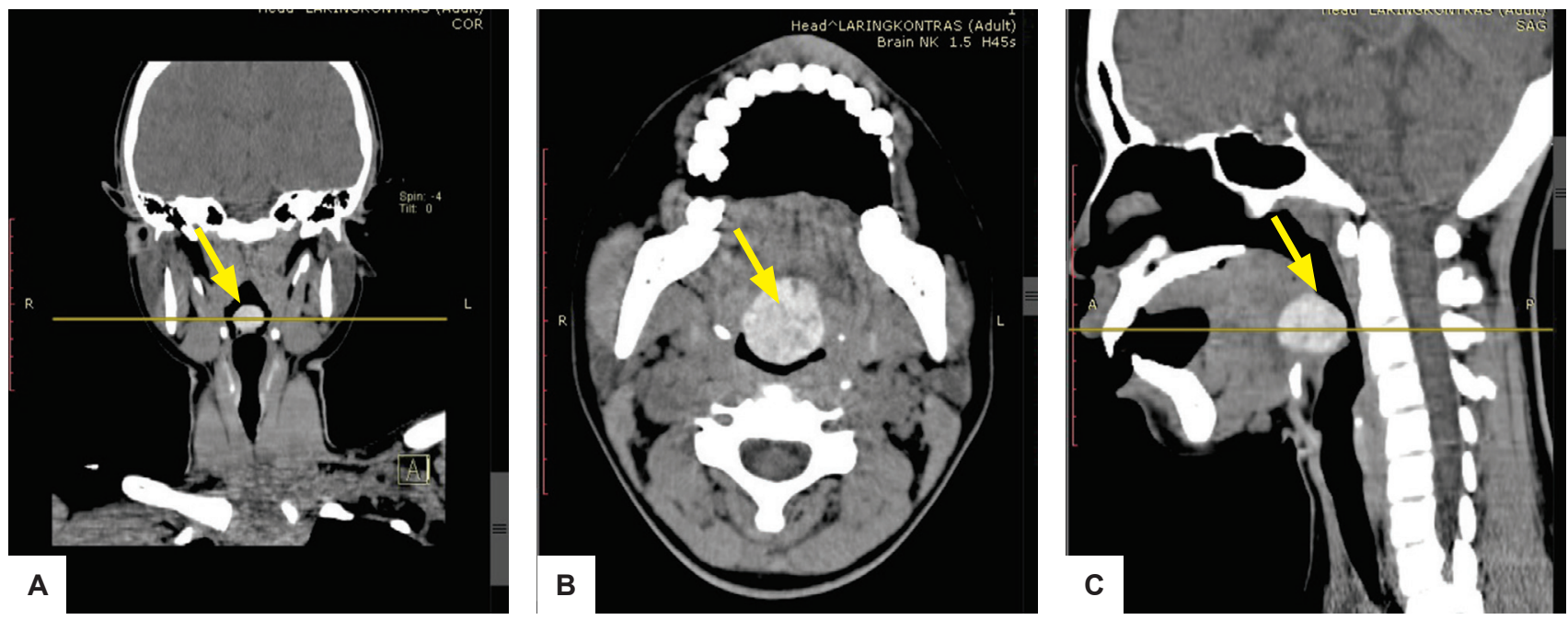

Figure 2. Head and neck CT scan examination. (A) Coronal and (B) axial enhanced neck CT scan demonstrates welldefined homogeneous enhancing mass without calcification (yellow arrows); (C) A sagittal enhanced CT scan of the neck demonstrates enlargement of the thyroid gland. It shows the location of the thyroid gland above the normal thyroid (sublingual position) (yellow arrow).

ISSN 0857-1074 (Print) I eISSN 2308-118x (Online) Printed in the Philippines

Copyright ( $(2) 2021$ by Windradi et al.

Received: May 28, 2021. Accepted: August 24, 2021.

Published online first: August 31, 2021.

https://doi.org/10.15605/jafes.036.02.15
Corresponding author: Choirina Windradi, MD

Department of Internal Medicine, Faculty of Medicine,

Airlangga University, General Teaching Hospital Dr. Soetomo

Jl. Mayjen Prof. Dr. Moestopo No. 6-8, Airlangga, Kec. Gubeng

Surabaya, East Java, 60115, Indonesia

Tel. No.: (031) 5501078

E-mail:chylonly@gmail.com

ORCiD: https://orcid.org/0000-0002-3394-400 


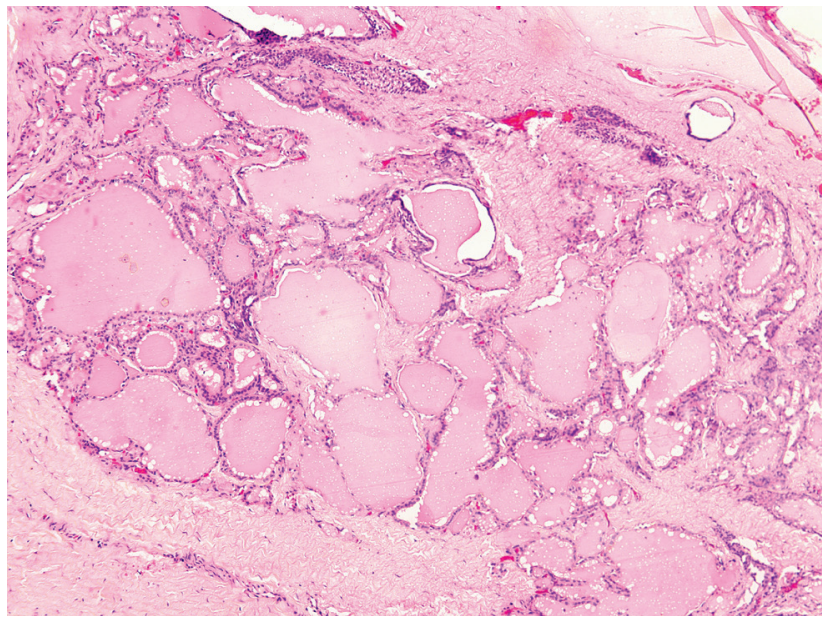

Figure 3. Microscopic examination shows various sized thyroid follicles with hyperplastic change (H\&E, 400x).

The ectopic thyroid is a rare congenital disorder with incidence between 1:3000 - 1:300000 although it could present with thyroid dysfunction. Most ectopic thyroid cases are euthyroid, only a few patients are subclinically hypothyroid. ${ }^{1}$ It is usually aysmptomatic but as the mass increases it can cause obstructive symptoms. ${ }^{2}$ At the age of puberty, thyroid hormone deficiency causes hypertrophic glands and results in obstructive symptoms. Asymptomatic cases can be monitored with serial exams or receive hormonal therapy with levothyroxine. However, such treatment does not have a good success rate. The reduction in size occurs very slowly, without significant decreases in volume. ${ }^{1}$ Therefore, the decision to excise the mass was made for this patient. After surgery, monitoring of symptoms and thyroid hormone levels should be done regularly. Levothyroxine supplementation is recommended to prevent overt hypothyroidism and to suppress production of TSH.,4

Ethical Consideration

Patient consent was obtained before submission of the manuscript.

Statement of Authorship

All authors certified fulfilment of ICMJE authorship criteria.

\section{Author Disclosure}

The authors declared no conflict of interest.

\section{Funding Source}

None.

\section{References}

1. Xavier CRS, Medeiros LFB, Freire AD, et al. Lingual thyroid Literature review. Arch Med. 2016. https://www.archivesofmedicine. com/medicine/lingual-thyroidliterature-review.php?aid=9572.

2. Allen E, Alzeerah M, Tsiao S, Aydin N, Misra S. A unique presentation of ectopic thyroid, a case report. Int J Surg Case Rep. 2016;29:185-8. PMID: 27866035. PMCID: PMC5121164. https://doi.org/10.1016/j. ijscr.2016.10.079.

3. Alexander EK, Pearce EN, Brent GA, et al. 2017 Guidelines of the American Thyroid Association for the diagnosis and management of thyroid disease during pregnancy and the postpartum. Thyroid. 2017;27(3):315-89. PMID: 28056690. https://doi.org/10.1089/thy.2016 0457.

4. Fatourechi V. Subclinical hypothyroidism: An update for primary care physicians. Mayo Clin Proc. 2009;84(1):65-71. PMID: 19121255 PMCID: PMC2664572. https://doi.org/10.1016/S0025-6196(11)60809-4.

Authors are required to accomplish, sign and submit scanned copies of the JAFES Author Form consisting of: (1) Authorship Certification, that authors contributed ubstantially to the work, that the manuscrint has been read and approved by all authors, and that the requirements for authorship have been met by each author; (9) the Author Declaration, that the article represents original material that is not being considered for publication or has not been published or accepted for publication elsewhere, that the article does not infringe or violate any copyrights or intellectual property rights, and that no references have been made to predatory/suspected predatory journals; (3) the Author Contribution Disclosure, which lists the specific contributions of authors; (4) the Author Publishing Agreement which retains author copyright, grants publishing and distribution rights to JAFES, and allows JAFES to apply and enforce an Attribution-Non-Commercial Creative Commons user license; and (5) the Conversion to Visual Abstracts (*optional for original articles only) to improve dissemination to practitioners and lay readers Authors are also required to accomplish, sign, and submit the signed ICMJE form for Disclosure of Potential Conflicts of Interest. For original articles, authors are required to submit a scanned copy of the Ethics Review Approval of their research as well as registration in trial registries as appropriate. For manuscripts reporting data from studies involving animals, authors are required to submit a scanned copy of the Institutional Animal Care and Use Committee approval. For Case Reports or Series, and Images in Endocrinology, consent forms, are required for the publication of information about patients; otherwise, appropriate ethical clearance has been obtained from the institutional review board. Articles and any other material published in the JAFES represent the work of the author(s) and should not be construed to reflect the opinions of the Editors or the Publisher.

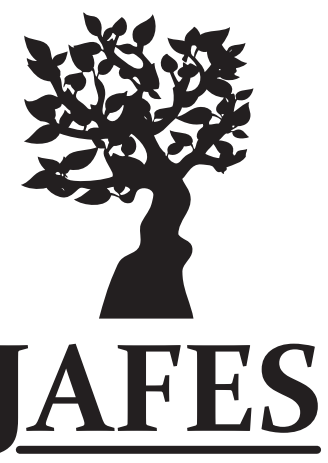

A new venue for publishing your original articles. Visit www.ASEAN-endocrinejournal.org for Instructions to Authors. 